\title{
Trade Liberalisation and Poverty Dynamics in Vietnam
}

\author{
Yoko Niimi \\ The World Bank \\ Puja Vasudeva Dutta \\ The World Bank \\ L. Alan Winters \\ University of Sussex
}

\begin{abstract}
This paper explores the poverty impact of Vietnam's trade liberalisation over the 1990s and asks how well they could have been predicted from prior data. We identify policy changes and their major effects on trade and prices. We then seek the effects of these changes in a panel comprising 4,302 households observed in 1993 and 1998. Using a multinomial logit model, we find evidence that trade liberalisation influenced household poverty status and that considering trade effects would help to identify winners and losers a priori. We also find evidence that trade liberalisation reduced poverty substantially over the period 1993-1998.
\end{abstract}

- JEL classification: F13, F14, I32, O15, O24

- Keywords: Trade policy, Poverty, Vietnam

\footnotetext{
*Corresponding address: Yoko Niimi, Development Research Group, The World Bank, 1818 H Street NW, Mail-stop MC3-303, Washington, DC 20433, USA. Tel: +1-202-4585912, Fax: +1-202-5221159, E-mail: yniimi@worldbank.org.

**Puja Vasudeva Dutta, Human Development Unit, The World Bank, 70 Lodi Estate, New Delhi 110003, India. Tel: +91(11) 41479156, Fax: +91(11)24619393, E-mail: pdutta@worldbank.org.

***L. Alan Winters, Department of Economics, University of Sussex, Brighton, BN1 9SN, UK. Tel: +44(0)1273-678332, Fax: +44(0)1273-673563, E-mail: L.A.Winters@ sussex.ac.uk

@ $2007-$ Center for International Economics, Sejong Institution, All Rights Reserved.
} 


\section{Introduction}

The link between trade liberalisation and poverty is one of the most contentious areas of debate within the development community. Both sides of the debate, however, rely more on theory, rhetoric and anecdote than on solid empirical research. This paper starts to redress the balance through a study of the recent trade liberalisation in Vietnam using the conceptual framework developed by Winters (2000, 2002). In addition to the long-run effects operating through economic growth, Winters considers the static effects of trade shocks on households, directly via product and factor markets, and indirectly through changes in government revenues and social spending. This paper explores some aspects of the poverty effects of Vietnam's trade liberalisation over the 1990s and asks, in particular, how well the framework would have performed if it had been applied to this case at the outset.

Vietnam is an ideal candidate for such a test in the sense that it has two surveys of substantially the same households in 1992-1993 and 1997-1998 - the Vietnam Living Standards Surveys. ${ }^{1}$ Hence throughout the paper we focus on this five year period, and because five years is too short a period to assess the impact of openness on economic growth, ${ }^{2}$ on the static effects felt via prices, wages and employment. In another sense, however, Vietnam is less than ideal. Since the start of the doi moi reforms in 1986 the Vietnamese economy has been undergoing a more or less continuous transition from a centrally planned socialist to a marketoriented economy. Although this process has, at times, been halting and confused and is certainly not yet complete (see van Donge, White and Nghia (1999)), it seems to have had quite marked effects on the economy. Thus a major challenge for research of this kind is to identify the international trade reforms that have actually occurred, separate them from other shocks and trace their transmission through to poor households.

\footnotetext{
${ }^{1}$ These surveys were carried out by the General Statistical Office (GSO) and the Ministry of Planning and Investment, with financial assistance from the United Nations Development Programme (UNDP) and the Swedish International Development Agency (SIDA) and technical assistance from the World Bank.

${ }^{2}$ Given that it takes time for trade liberalisation to have an effect on the economy, a longer span of data, for instance between the early 1990s and early 2000s, must also be examined in future research. It should be noted, however, that the Vietnam Household Living Standard Survey (VHLSS) 2002 did not revisit the households that were surveyed both in 1992-93 and 1997-98, so the panel approach we adopt here would no be feasible for that period.
} 
The next section briefly reviews the reforms undertaken in Vietnam during the 1990s and their impact on the Vietnamese economy. In section 3 the mechanisms through which these macro-level reforms impact households are analysed using the framework provided by Winters focusing on the price and the labour market channels. Section 4 explores the effect of trade liberalisation on poverty using the household survey data to estimate a multinomial logit model (and certain other models) of the transition between poverty and non-poverty incorporating the key trade links identified in the empirical analysis in the previous section. Section 5 concludes by asking how liberalisation appears to have affected poverty and, more directly, whether the maintained framework provides insight on the links between trade liberalisation and poverty.

\section{Economic Reform and Trade Liberalisation in Vietnam ${ }^{3}$}

The process of 'economic renovation' or doi moi was set in motion in 1986 and gathered momentum in the early 1990s with the objective of transforming Vietnam from a centrally planned to a market economy. The institutional reforms during this period included the encouragement of the private sector and establishment of legal basis for contract, banking and financial sector reforms, taxation reforms, establishment of economic courts, consolidation of property rights, land reforms, and the rationalisation of state-owned enterprises (SOEs).

\section{A. External Sector Reform}

An important facet of doi moi was the dramatic change in external sector policy from inward-oriented import substitution to outward-orientation. Vietnam's major external sector reforms included (see Niimi et al. (2003) for a more detailed review):

- The removal of constraints on trade outside the CMEA bloc, ${ }^{4}$

- The rationalisation and unification of the exchange rate in 1989 and further liberalisation of foreign exchange controls: by 1993 all foreign transactions were in convertible currency,

\footnotetext{
${ }^{3}$ This review draws on Andersen (1994), CIE (1998), Martin (2000) and CIEM (2001).

${ }^{4}$ The Council of Mutual Economic Assistance (CMEA) consisting of the former Soviet Union, Eastern European socialist countries and Cuba.
} 
- The relaxation of import and export controls and a move towards a tariff based system of trade management,

- Export promotion and the establishment of export processing zones,

- The relaxation of controls on entry into foreign trading activity and the simplification and eventual elimination in 1998 of the licensing procedure,

- The initiation of an 'open door policy' to promote foreign investment and the creation of a legal framework to approve and regulate foreign direct investment (FDI), and

- Integration with the world economy via regional and multilateral trading agreements.

Customs tariffs were introduced in 1988 for the first time and the Harmonised System (HS) was introduced in 1992. By 1998 the management of imports of most consumer goods had shifted from quotas or licensing to tariffs although eight categories of goods remained under quantitative restrictions. The maximum and average tariff rates (especially on consumer goods) have remained high, and although the average tariff rates do not seem out of line with those in other developing countries, most imports fell in the higher tariff brackets (see Table 1). In addition, there have been several retrogressive measures in the form of rising export taxes, temporary prohibitions on imports of consumer goods, and other barriers introduced as anti-smuggling measures. Overall, both the import tariff and export tax systems are complex and suffer from frequent changes (CIEM, 2001), so that despite all the reforms, Vietnam's trade regime must be considered to

Table 1. Indicators of Nominal Tariff in Vietnam, 1992-2000

\begin{tabular}{lccccccccc}
\hline & 1992 & 1993 & 1994 & 1995 & 1996 & 1997 & 1998 & 1999 & 2000 \\
\hline Share of tariff lines & & & & & & & & & \\
0-10 percent & 68 & 66 & 66 & 66 & 64 & 63 & 63 & 59 & 60 \\
Above 10-20 percent & 15 & 14 & 13 & 13 & 12 & 13 & 12 & 10 & 9 \\
Above 20-40\% & 15 & 15 & 16 & 16 & 18 & 18 & 19 & 21 & 21 \\
Above 40\% & 2 & 5 & 5 & 5 & 6 & 6 & 6 & 10 & 10 \\
(No. of tariff lines) & $(2813)$ & $(2967)$ & $(2934)$ & $(3023)$ & $(3180)$ & $(3126)$ & $(3163)$ & $(6056)$ & $(6341)$ \\
Average rate & 10.7 & 11.8 & 12.3 & 12.3 & 12.9 & 13.4 & 13.6 & 16.3 & 16.2 \\
Maximum rate & 120 & 150 & 200 & 200 & 100 & 200 & 60 & 100 & 100 \\
Standard deviation & 14.8 & 16.7 & 17.5 & 17.3 & 16.1 & 17.0 & 15.9 & 18.7 & 19.1 \\
Number of rates & 26 & 31 & 35 & 34 & 30 & 35 & 28 & 12 & 19 \\
\hline
\end{tabular}

Source: CIEM (2001:17).

Note: a) Simple average 
remain quite restrictive and interventionist (IMF, 1999).

With its multiple interventions and extensive use of administrative fiat, the complexity of Vietnam's trade policy regime makes it impossible to trace the effects of specific policy changes back to households. Hence we are obliged to use outcomes - prices and quantities - in order to identify the impact of the trade liberalisation. Relative prices and the openness of the Vietnamese economy have changed dramatically over the 1990s, so there is a strong presumption that the external sector will have had significant effects on poverty. Moreover, although Vietnam undertook dramatic reforms of both domestic and external policies so that there remains considerable uncertainty about precise attribution, it is entirely reasonable to assume that at least a significant proportion of the trade shock originated in trade policy changes.

\section{B. Macroeconomic Outcomes}

Despite their incompleteness, the impact of the reforms on the Vietnamese economy has been tremendous. The economy grew at approximately 7-8 percent per annum between 1990 and 2000 and over 5 percent even following the Asian crisis in 1997. Firm domestic credit policies, tight monetary policies and interest rate reforms stabilised the hyperinflation of the 1980s, and the exchange rate remained relatively stable after the rationalisation of the multiple exchange rate system and successive devaluations (CIE, 1998). The reforms induced large FDI inflows averaging 9 percent per annum of GDP between 1993 and 1997 although this declined after the Asian crisis in 1997. The data on FDI are weak, but the broad picture is that the majority was in the form of joint ventures with SOEs and was concentrated in high-cost, capital- and import-intensive industries with low employment impact (IMF, 1999).

\section{$\underline{\text { Trade }}$}

The share of trade in GDP increased from about 52 percent to 71 percent between 1993 and 1998 (GSO statistics). ${ }^{5}$ The external sector reforms stimulated strong export growth for commodities in which Vietnam apparently has a comparative advantage. By 2000 the combined exports of the textile and garments industry (one of the fastest growing export sectors) and the footwear industry were

\footnotetext{
${ }^{5}$ There are discrepancies in trade data between various sources, possibly due to the treatment of transit centres like Singapore, North Korea and Hong Kong (Apoteker, 1998). However, all sources tell the same sort of story about the increase in openness.
} 
higher than those of the four chief agricultural exports - rice, coffee, rubber and marine products (CIEM, 2001; IMF, 1998, 2000). And this was despite the fact that Vietnam switched from being a net importer of rice in the 1980s to being the world's second largest exporter of rice by volume by 1996 (Nielsen, 2002). Imports continued to be dominated by machinery and intermediate goods (amounting to approximately 70 percent of total imports), reflecting both the industrialisation of the Vietnamese economy and the structure of protection with its bias against imports of consumer goods (IMF, 1998, 2000).

\section{The rice sector}

Since it figures so prominently in Vietnamese life, we should consider briefly the rice market. Niimi et al. (2004) discuss the sector in more detail. The decollectivisation of agriculture and land reform in 1988 greatly increased the incentives to produce rice. Domestic prices were liberalised in 1989. Simultaneously, international trade in rice was liberalised with the result that exports boomed and prices rose. Between 1993 and 1998, our period of analysis, real rice prices (relative to the CPI) rose by nearly 30 percent. In a related development real fertiliser prices fell by 23 percent between 1992-1993 and 1997-1998. Since nearly all fertiliser requirements were met by imports and these were regulated by quota with the objective of stabilising domestic prices and keeping average prices significantly above world prices (Nielsen, 2002), we interpret this as a significant and conscious trade liberalisation.

To summarise, "the foundation for Vietnam's success - and the core of the doi moi program - has been a combination of liberalization, stabilization, institutional changes, and some structural reform" (Kokko, 1997:1). The economic reforms generated high growth during the 1990s characterised by increasing exports and foreign investment, expanding private sector as well as state enterprise activity, and declining inflation. The relatively egalitarian distribution of land, the stress on agriculture during doi moi and the subsequent high growth of the economy suggest that the restructuring of the economy might have had a favourable impact on the poor in Vietnam. Glewwe et al. (2002) find that, based on the official poverty line, absolute poverty incidence declined from 58.1 percent to 37.4 percent between 1992-1993 and 1997-1998. ${ }^{6}$ The next section traces the product and labour market channels through which the trade reforms might be expected to have impacted poor

\footnotetext{
${ }^{6}$ Justino and Litchfield (2004) find that alternative poverty lines also imply strong declines in poverty.
} 
households.

\section{Trade Liberalisation and Poverty: Prices and Employment}

Winters (2002) develops a framework for exploring the links between trade shocks and poverty by considering its effect on the prices of tradable goods and hence to changes in household and individual welfare. A key concept is the socalled 'farm household' - a household which potentially makes production as well as employment and consumption decisions (see, for example, Singh, Squire and Strauss, 1986). In this section the effects of trade policy on poor households are explored via their direct effects on product and factor markets, that is, in terms of product price and labour market changes. The analysis focuses on identifying critical trade links between 1992-1993 and 1997-1998 because these are the two years that representative Vietnam Living Standards Surveys (VLSS) are available. These trade links are then incorporated into the econometric analysis of household poverty dynamics in the next section.

\section{A. The Price Channel}

Trade-induced price changes in product markets affect both the nominal and real incomes of households in their capacity as producers as well as consumers. The lowering of tariff barriers is likely to reduce the price of imported goods in the domestic market, and at the same time export liberalisation may lead to higher prices for exported goods. The direction and strength of these effects on real incomes depend on whether households are net buyers or net sellers of the products concerned (Winters, 2002).

The dramatic policy-induced development of Vietnam's export sector and import liberalisation would lead one to expect significant changes in the prices of some tradable commodities. Table 2 reports the proportionate changes in the real retail prices of the selected consumer goods and services (from GSO statistics). ${ }^{7}$

It is clear that Vietnam's leading export products such as rice and marine products saw relatively higher price increases during this period than did other products. Rice is the most important single source of income for the majority of Vietnamese households, accounting for about 30 percent of household income in

\footnotetext{
${ }^{7}$ These figures need to be treated with some caution as most of the individual prices increase. The nominal prices were deflated by the CPI obtained from GSO, but the information on how the CPI was constructed is not available.
} 
Table 2. Price Movements 1993-1998 (percent)

\begin{tabular}{lc}
\hline Consumer Goods/Services & Change \\
\hline Mackerel & 76.87 \\
Vitamin C & 40.40 \\
Permanent wave & 35.49 \\
Sea shrimps & 33.31 \\
Fish sauce & 32.53 \\
Paddy & 26.15 \\
Spring rice & 26.05 \\
Salt & 21.55 \\
Beef topside & 21.30 \\
Glutinous rice & 20.68 \\
Haircut & 16.50 \\
Cotton fabrics & 13.75 \\
Supply water & 13.65 \\
Chicken carcass & 11.80 \\
Duck's eggs & 10.76 \\
Petrol & 10.39 \\
Papers & 3.46 \\
Fresh carp & 0.90 \\
Shelled nuts & 0.37 \\
Black beans & -0.69 \\
Green beans & -1.95 \\
Soya curd & -1.99 \\
Glutamate & -3.24 \\
Soya beans & -3.66 \\
Pork & -4.03 \\
Kerosene & -4.44 \\
White sugar & -6.29 \\
Electricity & -17.78 \\
Vitamin B1 & -18.17 \\
Beer & -22.45 \\
Photograph & -25.23 \\
Woollens & -37.97 \\
CPI (percent Change) & 48.5 \\
\hline Sour & \\
\hline
\end{tabular}

Source: Calculations based on GSO statistics (provided by CIEM). Nominal prices deflated by official CPI index.

1998 (World Bank, 1999). As a result, changes in rice prices following liberalisation would have a significant impact on Vietnamese households. It is not 
possible to insist that these price increases were due solely to trade liberalisation, but there seems very likely to be a strong trade component. Although the price data are not available for coffee, which was another booming export commodity in Vietnam over our sample period, secondary sources - for example, Minot (1998) support the favourable effect of liberalisation-induced price changes on producers. However, more recently these households have been shown to be vulnerable to the considerable volatility of international coffee prices so some care must be taken not to interpret relatively short runs of data as implying permanent effects.

In contrast to their benefits for producers, price increases in consumer goods, especially rice, harm net consumers. According to our calculations based on the VLSS 92-93, rice on its own accounted for 44 percent of total food expenditure on average, and 53 percent for poor households: rice alone comprises about 75 percent of the total calorific intake of the typical Vietnamese household (Minot and Goletti, 1998). Clearly rice prices will be a major determinant of poverty, and in Niimi et al., (2004) we offer a full analysis of the rice market and the importance of different household consumption patterns in determining the poverty impacts of the rice price increases.

\section{B. The Employment and Wage Channel}

The other major channel through which foreign shocks are transmitted to poverty is through factor markets. The changes in product prices that accompany trade reform could lead to changes in the composition of output, and hence in the bundle of factors used in production. There are two ways that trade-induced changes in the factor market can affect households - through wage changes or through employment changes depending on whether the labour supply is taken to be fixed or flexible (Winters, 2002). Although the impact of trade reforms via the labour channel is expected to be limited because the bulk of the labour force in Vietnam is selfemployed (Gallup, 2004), it is still of sufficient potential interest to warrant attention.

\section{Employment and wage trends}

The doi moi reforms had a substantial impact on the sectoral composition of output growth. The industrial and services sectors grew rapidly, outpacing the growth in the agricultural sector during the 1990s. Despite the high output growth, however, total employment apparently grew by only about 2-3 percent in this entire period (IMF, 1998, 2000) and was characterised by the absence of job creation in the industrial sector despite its being the fastest growing sector (Belser, 1999). 
Probably related is the fact that the state sector is still predominant in the Vietnamese economy, especially in the industrial and services sectors. Despite the large output share at around 40 percent of the GDP (GSO statistics), the share of the state sector in total employment is only about 10 percent. Both unemployment and underem- ployment ${ }^{8}$ in urban and rural areas declined until the Asian crisis hit Vietnam in 1997, reaching about 6.9 percent and 1.4 percent respectively in 1998, although with considerable regional variations (CIEM, 2000, World Bank, 1999). Estimates from the VLSS data reveal that wage employment expanded marginally from 24 to 25 percent of the labour force between 1993 and 1998 (Gallup, 2004).

There is some disagreement about wage movements given the paucity of wage data. Chandrasiri and de Silva (1996) use ILO data to argue that real wages fell following liberalisation, while the IMF $(1998,2000)$ seems to suggest that real earnings (covering all cash income including payments in kind, bonus payments, and social security contributions) increased strongly. The VLSS data indicate that real hourly earnings grew rapidly at about 10.5 percent per annum between 1993 and 1998. There are wide regional differences, however, with Ho Chi Minh City and Hanoi having higher earnings and experiencing faster growth in earnings (Gallup, 2004).

There are considerable earnings differentials depending on sector of employment (state or non-state, foreign-invested), education and region (Chandrasiri and de Silva, 1996, O'Connor, 1996). Although minimum wage levels have been prescribed for both domestic and foreign-invested enterprises, average unskilled wages are about three times higher than the minimum in all forms of employment, and exceed the minimum even in small household enterprises (Belser, 1999).

\section{The trade-labour link}

The macroeconomic trends in employment and wages described above suggest the absence of any significant employment effect. Whether this is because trade effects are minor or because they have been offset by other factors can be explored by formally exploring how trade shocks have been transmitted through the labour

\footnotetext{
${ }^{8}$ 'Underemployed' is defined as working less than 40 hours per week.

${ }^{9}$ We thank Azita Amjadi of the World Bank for assistance with these data.

${ }^{10}$ Partner data are used as Vietnamese data are not available in sufficient detail. Partner data account for approximately 90 percent of Vietnam's total exports and imports (GSO statistics) for each year. See Niimi et al. (2005) for further details about the trade data used.
} 
market. A first step towards this is to identify major changes in trade patterns and then to explore whether output or employment in these sectors has identifiable consequences for poverty dynamics.

We use mirror statistics from the UN Comtrade system ${ }^{9,10}$ in order to identify the sectors that showed the biggest absolute increases in export and import flows between 1993 and 1998. In the case of exports, light industrial products such as footwear, garments and electrical parts, and primary commodities including rice, coffee, seafood and petroleum are found to be the main export growth commodities. In contrast, imports are dominated by capital and intermediate products. This seems to accord with a factor endowment view of comparative advantage. These key sectors are now carried forward to our econometric modelling of household poverty dynamics in the next section. In Niimi et al. (2005), however, we explore the consequences of the trade changes for net labour demand in some detail, including a factor content of trade analysis. This suggests that the employment and wage effects of trade reforms in Vietnam were real but not particularly deep.

\section{An Econometric Analysis of Household Poverty}

The previous section suggested some of the possible poverty impacts of trade reform on the basis of descriptive statistics. This section assesses whether the observable dimensions of liberalisation have influenced household outcomes and contributed to poverty alleviation using formal analysis of household data - mainly by means of a multinomial logit model. Specifically we ask whether production characteristics that would a priori dispose a household towards an escape from poverty actually do so. In essence, adopting Glewwe et al.'s model of the structure of Vietnamese poverty, we estimate a model describing the probabilities of a household staying in or escaping from poverty and ask whether the trade links identified above contribute to the explanation. If they do, the framework advanced above and in Winters (2002) is useful analytically and we can start to explore whether the policy changes have helped or hindered poverty reduction.

\section{A. Modelling the Economics of Liberalisation}

A household is considered to be poor in the VLSS if $c^{\prime} p \leq \bar{c}^{\prime} p$, where $\mathrm{c}$ is its consumption basket, $p$ the vector of prices and $\bar{c}$ the 'poverty' basket. Aggregate consumption can be expressed as aggregate income less savings: 


$$
c^{\prime} p q^{\prime} p+f^{\prime} w+m-s
$$

where $q$ is the production vector (negative for inputs), $f$ is a vector of holdings of income generating assets or household characteristics, $w$ the related vector of returns, $m$ 'non-produced' income and s savings. Ignoring savings for lack of data, we essentially use a regression framework to explain changes in the sign of $\left(c^{\prime} p-\bar{c}^{\prime} p\right)$ in terms of changes in income, ${ }^{11}\left(q^{\prime} p+f^{\prime} w+m\right)$, that is, in terms of

$$
d\left(q^{\prime} p+f^{\prime} w+m\right)=\left[q^{\prime} d p+(d q)^{\prime} p+f^{\prime} d w+(d f)^{\prime} w\right]+d m
$$

For reasons we discuss below, we focus only on predetermined assets or characteristics, so this expression reduces to:

$$
d\left(q^{\prime} p+f^{\prime} w+m\right)=\left[q^{\prime} d p+f^{\prime} d w\right]+d m
$$

where $q$ and $f$ are data, and, where, because they are basically unknown, $d p$ and $d w$ are to be estimated from the coefficients of the regression model. In fact, this 'change in price' interpretation of the coefficients of our estimated functions is too strict given all the missing variables and specification difficulties we face, but the basic idea is useful: we are asking how well can we predict changes in poverty status given households' initial (pre-reform) sets of outputs/inputs characteristics and activities. While it is possible that ignoring the change in assets could generate an omitted variable bias we felt it desirable to focus on initial conditions alone to avoid simultaneity problems. This is particularly likely to be a problem as the available data pertains to output not assets.

The modelling in this section is related to that in Glewwe et al. (2002) and Justino and Litchfield (2002), but differs in a number of important respects. First, our work is more closely focussed on the trade effects than the general dynamics of poverty in Vietnam. Second, we explore both urban and rural populations: although the rice story is rural, the growth of light manufactured exports is essentially urban. Third, with one exception, we limit ourselves to pre-determined variables as regressors, so as to avoid any hint of simultaneity; this is a strict discipline, for it expressly excludes the effects of changes in activity in response to trade reform.

\footnotetext{
${ }^{1}$ This is clearly a heroic assumption, although quite common in household studies with inadequate income data. It would be legitimate if $s$ were a constant plus a random term, although this is not likely. It would also not be serious if savings were proportionate in income for it would merely scale the coefficients on the components of income. In fact, the probability that savings are correlated with our included regressors - e.g. urban households having better access to financial institutions and hence more likely to save - is a possible source of bias. However, as long as these correlations were not changing between our two observations, we would not distrust our evidence of the correlates of escaping from poverty.
} 
However, since our purpose is to explore whether trade has identifiable poverty impacts and to see how the framework of Winters (2002) helps us identify them a priori, the fact that our approach tends to lead us to underestimate the role of trade seems constructive. We discuss this more fully below. Finally, there are small differences in the sets of included demographic variables and their measurement.

\section{B. Description of the Data}

The VLSS contains two waves of data: 4,800 households in 150 communes surveyed over October 1992 to October 1993 and 6,000 households in 194 communes surveyed over December 1997 to December $1998 .{ }^{12}$ The samples are believed to be representative for the respective years and, critically, over 4,300 households are identifiably surveyed in both waves. 89.6 percent of households from VLSS 92-93 were questioned in VLSS 97-98, and the remainder in the latter were randomly selected. Although attrition means that our panel is not a nationally representative sample of Vietnamese households in a strict sense, this panel dimension allows us a much better view of the dynamics of poverty than would two similar-sized unrelated cross-sections. Furthermore, Falaris (2003) demonstrates that survey attrition in the VLSS (1992-93 and 1997-98) does not have a major impact on the estimation of statistical models.

Table 3 reports sample sizes for the four groups defined by poverty status in 1992-1993 and 1997-1998. The rural and urban samples are pooled together. The rural sample is sizeable, although, even here, the numbers slipping into poverty are small. The urban sample is smaller - certainly too small to permit independent estimation. The urban sample is included in the analysis in order to identify the role of employment in the export-oriented sectors identified above and these sectors are largely concentrated in urban areas.

Table 3. Poverty Transition Matrix (1992-1993 and 1997-1998)

\begin{tabular}{cccccc}
\hline & \multicolumn{2}{c}{ Rural } & & \multicolumn{2}{c}{ Urban } \\
\cline { 1 - 2 } \cline { 5 - 6 } $1997 / 98$ & Poor & Non-Poor & & Poor & Non-Poor \\
\hline $1992 / 93$ & & & & 52 & 139 \\
Poor & 1184 & 1037 & & 17 & 600 \\
Non-Poor & 187 & 1086 & & 17 \\
\hline
\end{tabular}

Source: Calculations based on the VLSS 92-93 and 97-98.

Note: The figures in the table are the actual number (unweighted) of households in the panel data set.

${ }^{12}$ Justino and Litchfield (2004) give more detail. 
The poverty line used in this work is the official poverty line, which is based on calorie intake. Based on the consumption basket of the third quintile of households in 1992-1993, the poverty line is the cost of purchasing 2,100 calories per head per day plus an allowance for non-food costs, valued at national prices. Its value is 1.160 million dong in 1992-1993 and 1.790 million dong in 1997-1998. Reported consumption or expenditures in the VLSS are deflated by regional price indices constructed from CPI data disaggregated by region and rural/urban sector - before applying the poverty line (World Bank, 2001). Glewwe et al. (2002) argue that the VLSS data on incomes are too unreliable for analysis, so we follow them and measure poverty in terms of aggregate consumption. For simplicity, we opt for consumption per capita based on Burgess et al.'s (2000) argument that using adult equivalent scales makes little difference to this kind of analysis. ${ }^{13}$

One consequence of the definition of poverty adopted (that is, in terms of a standardised consumption basket) is that households' actual consumption baskets do not affect our estimates of their poverty status, thus short-circuiting one of the links from trade reform to poverty discussed in section 3.1. In Niimi et al. (2004) we describe the calculation of consumption and poverty lines in more detail and explore the importance of differences in consumption baskets for our results. They turn out to be very robust in this regard and so we do not pursue the issue here. The approach used in this paper differs in this respect from that followed by Minot and Goletti (1998) or Benjamin and Brandt (2004) who consider households' net positions in rice as a way of predicting ex ante the poverty effects of rice reform. ${ }^{14}$ Both studies predict that households, especially rural households, experienced rising real incomes (and declining poverty incidence) that could be linked, at least in part, with the rice market liberalisation but do not test their predictions.

\section{The Multinomial Logit Model}

The MultiNomial Logit (MNL) model analyses the probability of being in a particular state out of several unordered alternatives. We examine the poverty transition between 1992-1993 and 1997-1998 in terms of multiple (unordered)

\footnotetext{
${ }^{13}$ Per adult equivalent scales may deal better with differences in the intra-household allocation of goods and household economies of scale (White and Masset, 2003), but we do not believe that latter are likely to be very important, as food, the main expenditure of poor households, is not generally prone to large economies of scale.

${ }^{14}$ The methodology adopted by both studies is closely related to the work carried out by Deaton (1989), which examines the welfare effect of rice price changes on Thai farmers.
} 
choices - specifically (1) being poor in both periods $(\mathrm{P} \rightarrow \mathrm{P}),(2)$ being non-poor in the first period and becoming poor in the second period $(\mathrm{NP} \rightarrow \mathrm{P})$, (3) being poor in the first period and becoming non-poor in the second period $(\mathrm{P} \rightarrow \mathrm{NP})$, and (4) being non-poor in both periods ( $\mathrm{NP} \rightarrow \mathrm{NP})$. The probability that household $i$ experiences outcome $j$ is expressed as:

$$
\operatorname{Prob}\left(Y_{i}=j\right)=\frac{e^{\beta_{j}^{\prime} x_{i}}}{\sum_{k=1}^{4} e^{\beta_{k}^{\prime} x_{i}}}, \quad j=1,2,3,4
$$

where $Y_{i}$ is the outcome experienced by household $i, x_{i}$ is the $(\mathrm{n} \times 1)$ vector of characteristics for household $i$, and $\beta_{j}$ is the $(\mathrm{n} \times 1)$ vector of coefficients on $x_{i}$ applicable to households in state $j$. The model is identified only up to an additive vector since adding, say, vector $m$ to each $\beta_{k}$ leads to the same probabilities of $Y=$ $1, Y=2, Y=3$ and $Y=4$. Thus, one $\beta_{k}$ must be chosen as the base category and set to zero. All other sets are then estimated in relation to this benchmark. In most of our analysis, outcome 1 (the household is poor in both periods) is set to zero, since we are primarily interested in whether trade helps households to escape from poverty.

The empirical results in this paper are expressed as odds ratios - the probability of each outcome relative to the probability of the base category - rather than the MNL coefficients per se. If we set $Y=1$ as our base category, the odds ratio for $Y=2$ for a change in each variable $x$ is given by:

$$
\frac{\operatorname{Prob}(Y=2)}{\operatorname{Prob}(Y=1)}=e^{\beta_{2}^{\prime} x}
$$

where $e^{\beta^{(2)}}$ is the odds ratio for a unit change in the variable $x$. Since all continuous variables have been standardised, the coefficients represent the impact of a one standard deviation change in each explanatory variable on the odds ratio of the household being in each outcome. A coefficient less than one implies that the variable reduces the probability of the household being in the nominated category.

The MNL is most easily interpreted as giving conditional probabilities. Given that poor $\rightarrow$ poor is the base category, the coefficients for poor $\rightarrow$ non-poor (outcome 3 ) tell us the probabilities of moving out of poverty relative to being poor in both years. Similarly, the differences in the coefficients for non-poor $\rightarrow$ non-poor and those for non-poor $\rightarrow$ poor (i.e., remove "the ratio") give us the probabilities of

\footnotetext{
${ }^{15}$ The results of this regression are not reported as they mirror the first model.
} 
falling into poverty relative to being non-poor in both years. These latter are most easily calculated by re-estimating the equation with non-poor $\rightarrow$ non-poor as base and examining the coefficients for non-poor $\rightarrow$ poor. $^{15}$

The MNL is a common formulation for poverty work and was, as we noted, used by Glewwe et al. (2002) in their pioneering work on Vietnam. However, it is not without its drawbacks. One possible problem is the dichotomous nature of the poor/non-poor classification, which places arbitrary poverty lines at the heart of the analysis. This can be a particular problem given the inevitable errors of measurement in household expenditures (Deaton, 1997). ${ }^{16}$ In one set of experiments we truncate our sample around the poverty line to reduce the importance of random errors and also briefly discuss alternatives to the MNL (see section 4.6). Moreover, in compensation we note that by seeking to explain a categorical variable the MNL avoids measurement problems at the extremes of the distribution, where, arguably, they are likely to be at their worst.

We start from equations that are similar to those of Glewwe et al. (2002), and add a number of variables to reflect the trade links: rice production, coffee production, land and fertiliser use ${ }^{17}$ and the ratio of household members working in the leading export industries (seafood, food processing, garments, and shoes) to the number of adults in the household. The inclusion of the output data in 19921993 is designed to capture the benefits for self-employed households of prior specialisation in a booming export sector. The inclusion of variables on land is an attempt to see whether liberalisation affected the poor via (implicit) land rents, while the inclusion of fertiliser is to capture the benefits of the latter's significant price decline. The larger the household's use of fertiliser, the larger its net income gain as the price falls. In addition, there may be benefits to having an initial cropmix that could take advantage of the decline in price and increased availability of fertilisers. For rice, since production is highly correlated with the land and inputs usage, part of the effects of the latter should be captured by the production variable. However, as noted, fertiliser usage also has direct effects via the input vector, and land or irrigation may have asset-type advantages or reflect the availability of technologies that allow stronger or weaker than average responses to price shocks.

\footnotetext{
${ }^{16}$ Ravallion (1996) provides a useful discussion on the use of dichotomous variables for poverty measures.

${ }^{17}$ Our variable for the fertiliser use is constructed as the total amount of all kinds of fertilisers including urea, phosphoric fertilisers and NPK fertilisers.
} 
Given the centrality of rice to our story of Vietnamese poverty, it is at least worth checking these things. The benefits of being employed in the export sectors initially are represented by the employment variables.

In a few cases we measure certain demographic variables differently from Glewwe et al. (2002). In addition, since the VLSS interviews were spread over twelve month periods in both waves we also consider two timing variables. As there are signs of both seasonality and period-length effects, we add the dummy variables for the interview quarter in VLSS 92-93 and the period between surveys. ${ }^{18}$ We attempted to identify the effects of the Asian crisis of 1997 using the variables for the date of interviews for the VLSS 97-98. Although there appeared to be signs of the negative effects of the crisis in the later months of VLSS 97-98, none was significantly different from zero and we do not include these results in this paper. Presumably this means that Vietnam was not directly affected to the extent that some other countries were, ${ }^{19}$ although it is also possible that the adverse effects took longer to be felt at the household level than in aggregate or that the shock had been fully felt by December 1997, especially given that there was also a typhoon in the in 1997.

\section{Empirical Results}

The "basic" equation with no trade variables explains poverty dynamics as a

\footnotetext{
${ }^{18}$ The period between samplings could range from fifty to seventy-four months - equivalent to about 16 percent growth in income at average growth rates.

${ }^{19}$ This was perhaps partly due to the strict controls on the short- and long-term capital flows imposed by the State Bank of Vietnam.

${ }^{20}$ These regional dummies should capture, among other things, differences across regions on foreign aid and fiscal transfers from the government. We also tried to include a variable to control for fiscal transfers based on the VLSS 1992-93, more specifically social fund from the government. The results are not reported here as the inclusion of this variable might cause some endogeneity problems. However, we found that having received government funds in 1992-93 increased the probability of escaping from poverty and the inclusion of this variable hardly changed the estimated coefficients reported in this paper.

${ }^{21}$ The infrastructure variables are constructed on the basis of the commune questionnaires that were conducted along with the 1992-1993 and 1997-1998 VLSS. These data are available, however, only for rural communes in 1992-1993 and rural and small urban communes in 1997-1998. We used data for 1997-1998 to identify small urban communes which did not have these facilities in 1997-1998 and assumed they did not have them in 1992-1993 either. For the rest of urban communes, we assumed that they had access to these infrastructures. We experimented with an alternative assumption of universal urban provision since even if the facilities are not available in a commune, they are likely to be much more readily available than in rural communes without them. This hardly changed the results except for the coefficient on the urban dummy.
} 
function of region, ${ }^{20}$ ethnicity, demography, human capital (education), occupation, health, infrastructure and seasonality is reported in the Appendix. ${ }^{21}$ We report results for all three categories $(\mathrm{P} \rightarrow \mathrm{P}$ that is, being poor in both years is treated as base): being non-poor in 1992-1993 and poor in 1997-1998 $(\mathrm{NP} \rightarrow \mathrm{P})$, being poor in 1992-1993 and non-poor in 1997-1998 $(\mathrm{P} \rightarrow \mathrm{NP})$ and being non-poor in both years $(\mathrm{NP} \rightarrow \mathrm{NP})$.

In terms of the "basic" variables, although precise comparisons with Glewwe et al. (2002) and Justino and Litchfield (2002) are not feasible, they seem to tell a pretty consistent story. Location and regional effects, education and occupation of the household head, and infrastructure variables were among the major factors that increased the probability of escaping poverty relative to being poor in both years, while belonging to a minority ethnic group and illness of the household head increased the probability of falling into poverty relative to being non-poor in both years. ${ }^{22}$

The Appendix also reports the full model with the trade effects identified above added to the "basic" variables. The trade effects are largely orthogonal to the "basic" effects, so we report in the text only the coefficients on the various trade variables as they affect the chance of escaping from poverty.

Table 4 starts with our basic 'trade-inclusive' model (column A). The empirical analysis in section 3 identified rice, coffee, seafood and light manufactures as the principal areas of export growth. Hence we include among the regressors the household's initial production of rice and coffee and the proportion of workers initially holding jobs in export sectors (seafood, food processing - to allow for any processing of the primary exports - clothing and footwear). All have positive effects, the first two are strongly significant, both in the system as a whole and in explaining just the escape from poverty, whereas the last is strongly significant for the system as a whole but is significant in explaining the escape from and the descent into poverty only at the 10 percent level, indicating possible risk associated with these jobs. For example, ceteris paribus, a one standard deviation increase in a household's production of coffee more than doubles its chances of escaping from poverty in 1998, while a one standard deviation increase in rice output increases it by over 50 percent. Adding these three variables increases the pseudo- $\mathrm{R}^{2}$ of the system from 0.23 to 0.26 .

\footnotetext{
${ }^{22}$ See Niimi et al. (2003) for details.

${ }^{23}$ The rice production effect in the Mekong in column (B), Table 3 is an increase of 35 percent in the chance of escaping $=100 *(2.29 * 0.59-1)]$.
} 
Table 4. Odds Ratios for Escaping from Poverty (Results for Trade variables)

Model I (columns A-E): Base category - poor in both years

Model II (column F): Odds ratios for falling into poverty: Base category - non poor in both years

\begin{tabular}{|c|c|c|c|c|c|c|}
\hline & \multicolumn{5}{|c|}{ Model I } & \multirow{2}{*}{$\frac{\text { Model II }}{\mathrm{F}}$} \\
\hline & A & B & $\mathrm{C}$ & $\mathrm{D}$ & $\mathrm{E}$ & \\
\hline \multicolumn{7}{|l|}{ Agricultural variables } \\
\hline Quantity of rice production & $* * * 1.55$ & $* * * 2.29$ & $* * 1.67$ & $* * * 1.75$ & $* * * 1.77$ & $* 0.51$ \\
\hline In Mekong River Delta & & $* * * 0.59$ & $* * 0.63$ & $* * 0.60$ & $* * 0.60$ & 1.51 \\
\hline In Red River Delta & & $* 0.87$ & $* 0.86$ & $* * 0.85$ & $* * 0.85$ & 1.15 \\
\hline Quantity of coffee production & $* * * 3.00$ & $* * * 3.02$ & $* * * 2.32$ & $* * * 2.31$ & $* * * 2.31$ & 1.00 \\
\hline Quantity of fertiliser - rice & & & $* * * 1.41$ & $* * * 1.46$ & $* * * 1.46$ & 1.13 \\
\hline Qty. of fertiliser - non-rice & & & $* 1.59$ & $* 1.70$ & $* 1.71$ & $* 0.79$ \\
\hline \multicolumn{7}{|l|}{ Employment variables } \\
\hline $\begin{array}{l}\text { Ratio of household members } \\
\text { working in export }\end{array}$ & $* 1.11$ & & & $* * * 1.25$ & $* * * 1.23$ & $* 1.19$ \\
\hline Change in the ratio (export) & & & & $* * 1.17$ & $* 1.14$ & 1.06 \\
\hline $\begin{array}{l}\text { Ratio of household members } \\
\text { working in import }\end{array}$ & & & & & 1.12 & 1.09 \\
\hline Change in the ratio (import) & & & & & 1.07 & 0.95 \\
\hline $\begin{array}{l}\text { Ratio of household members } \\
\text { working in manufacturing }\end{array}$ & & & & & 1.06 & $* 0.80$ \\
\hline Change in the ratio (manufacturing) & & & & & 1.04 & 0.87 \\
\hline Pseudo R2 & 0.26 & 0.26 & 0.26 & 0.27 & 0.27 & 0.27 \\
\hline
\end{tabular}

Note: ***significant at 1 percent level; **significant at 5 percent level; *significant at 10 percent

(1) All the variables included in the "basic equation" (see Model 1 in the Appendix) are included as controls in this regression but not reported for brevity.

(2) The export sector includes seafood, food processing, garment and shoes (+rubber and plastic products).

(3) The categories for occupation slightly differ between the VLSS 92-93 and the VLSS 97-98.

(4) The import sector includes textile, machinery, leather, chemical and metal.

One important refinement to the rice result is its regional dimension (column B). The production effect is weaker in the Mekong River Delta than elsewhere. ${ }^{23}$ As well as being the major producing region for rice exports, the Mekong is also characterised by larger farms and a much greater use of hired labour (Minot, 1998). Thus, as production increases less of the benefit accrues to the householder as a producer and more to the labour he hires; correspondingly, household income owes more to wages deriving from others' rice production than it does elsewhere in 
Vietnam. We tried to test this last effect by including in the equation the proportion of household members reported to be working on someone else's farm (we cannot isolate rice farms). Its effect was positive but not statistically significant. A similar, but weaker, extenuation is also evident in the other major rice area, the Red River Delta. Here, although coefficient is significant only at 10 percent in the escape from poverty equation, it is strongly significant in the system as a whole ( $\chi^{2}$ at 3 degrees of freedom $=33.1$ ). Once these two regional variants are permitted the rice production effect elsewhere in the country increases to above two.

Column (C) of Table 4 adds variables for the initial use of fertiliser. Fertiliser prices fell by 23 percent in real terms between 1992-1993 and 1997-1998 and so heavy users could sustain material increases in real consumption. This is verified by estimation. In the table, however, we further refine the variable by distinguishing between rice and non-rice fertiliser effects. The logic is that non-rice use may reflect greater opportunities for exploiting the fall in price because farmers can switch between crops rather than just increase use for a single crop. Large initial users for non-rice crops may grow crops or farm under circumstances which respond to fertiliser usage and thus have greater opportunities for substitution than those who use little fertiliser to start with. ${ }^{24}$ The table shows strong positive effects from fertiliser use although non-rice use is significant only at 10 percent.

In Niimi et al. (2004) we also explore whether fixed inputs into agriculture (land and irrigation) and/or rice productivity have effects additional to those of the main outputs and inputs. The answer is 'no', which is as it should be: fertiliser has a direct income effect, while a kilo of rice yields the same net income whether you grow it on land to which you have firm rights or not. Hence, we do not pursue these variables further here.

The second major dimension of the trade liberalisation operates via the employment market. In column (A) of Table 4 we explore the benefits of working (initially) in the major export sectors by including the proportion of adults (15 years and older) holding a job in an export sector - seafood, food processing (because some seafood and rice exports are processed), clothing and footwear. The effects is benign - an 11 percent increase in the chance of escaping from poverty from a one standard deviation increase in the proportion of export workers (mean 0.046, standard deviation 0.156) - but it is not highly significant. When we sought separate effects for each export industry, they were mostly positive and that for

${ }^{24}$ We do not include the change in fertiliser use because of the obvious danger of endogeneity. 
seafood was significant, but there was no significant improvement relative to the combined variable shown in Table 4.

There are at least three ways of making a link between initial employment in an export sector and the escape from poverty. Existing workers could get real wage increases, which is a straightforward Heckscher-Ohlin or Ricardo-Viner-Jones result (coupled with an auxiliary assumption minimising churning in employment). Existing workers may be able to work longer hours (that is, a reduction in hidden unemployment or underemployment), as one might expect in transitional economies rationalising the state-owned sector. And finally, it may be that initial employment indicates a location close to exporting firms and hence better chances of the household obtaining more jobs as the firms expand.

In order to explore these possibilities more closely, we break our rule of using only initial values as explanatory variables, and add the change in the proportion of adults with employment in export sectors. This captures the third hypothesis above whereby an export boom generates more jobs but at constant real wages. Given the stock of workers in agriculture and SOEs and the relatively low skills required for most manufacturing export jobs, there is little reason to expect that new workers will be less productive than incumbents over the five years between our surveys.

Including the change in employment has negligible effects on all the other coefficients and their significance but quite strong effects on the initial employment. It increases from $1.11^{*}$ to $1.19^{* *}$, while the change in employment gets a coefficient of $1.14 * *$ (regression not reported). When the change in export employment is added to the model with agriculture modelled more fully (column C), the effects are even stronger - see column (D). Thus incumbency in manufacturing does have advantages in escaping poverty (via wages or hours presumably, neither of which we can test directly because the data are so noisy), but so does a household's ability to supply new workers.

Methodologically the lesson here is that for predicting the poverty effects of trade liberalisation, agricultural shocks may be well captured by initial activity in the affected sector because mobility is relatively low in these sectors. ${ }^{25,26}$ For manufacturing, however, although initial employment captures some of the likely

\footnotetext{
${ }^{25} \mathrm{By}$ the same token negative shocks will hit hard in agriculture, as, for example, the decline in coffee prices since 1997 is reported to have done in Vietnam's Central Highlands. ${ }^{26}$ Note that this cannot certainly be generalised if the low mobility is caused by the country-specific
institutional factor, namely Vietnam's household registration system.
} 
effects, some will be less predictable because mobility into manufacturing jobs is high.

If the labour market is reasonably well integrated, wage changes will not be restricted to the booming export sectors (as in Ricardo-Viner), but will spillover to other sectors (as under Heckscher-Ohlin). We test this by including in the equation the proportions of workers in import-competing sectors (textiles, leather, chemical, metals and machinery) and in all manufacturing, and changes in these ratios between the two years (column E). From the former we might also detect job losses as additional imports destroy jobs. The effects of employment in manufacturing are all positive, whatever the sector, but largest in exports, followed by imports and then by manufacturing in general. None of the import or manufacturing effects is significant, however. ${ }^{27}$ In interpreting column (E), it should be noted that both export and import industries are included in the general manufacturing set, so the gross effects are given by the products of two coefficients (for example, $1.23 * 1.06=1.30$ for export employment). Also, difficulties of classifying sector of occupation in 1997-1998 mean that the change in employment variables for exports and imports both include workers classified to the textiles and garments sectors.

We now briefly consider the descent into poverty. The sample for this is small and so the results in column $(\mathrm{F})$ of Table 4 are poorly defined. In an economy growing at 8 percent per annum with low levels of initial inequality descent into poverty is likely to be mainly an idiosyncratic event. Nonetheless, the results are broadly consistent with the analysis of escape from poverty even if they are not very significant statistically. The chances of falling back into poverty are reduced by higher rice output (in the Mekong and Red River Deltas as well), higher nonrice fertiliser use and prior employment in manufacturing. The last effect appears to be weaker in exporting $(1.19 * 0.80=0.95)$ than in other sectors, but is nonetheless still negative. One should not make much of this set of results, but they clearly lend some further support to our model of the poverty consequences of trade liberalisation.

While the trade effects appear to be estimated sufficiently precisely to reject the hypothesis that they have arisen by chance, we have not yet discussed their overall contribution to explaining poverty dynamics. We now ask how much better the fit

\footnotetext{
${ }^{27}$ Their insignificance persists even if the new variables are added one by one, except for import sector employment which is significant at 10 percent.
} 
Table 5. Goodness of Fit with and without Trade Variables

(A) Multinomial logit model without trade variables

The poverty status of about 59.90 percent of households was correctly predicted.

\begin{tabular}{lccccc}
\hline \multirow{2}{*}{ Actual } & \multicolumn{5}{c}{ Prediction } \\
\cline { 2 - 5 } \\
\cline { 2 - 5 } $\mathbf{P} \rightarrow \mathbf{P} \rightarrow \mathbf{P}$ & $\mathbf{N P} \rightarrow \mathbf{P}$ & $\mathbf{P} \rightarrow \mathbf{N P}$ & $\mathbf{N P} \rightarrow \mathbf{N P}$ & \\
& 844 & 0 & 208 & 184 & 1236 \\
$\mathbf{N P} \rightarrow \mathbf{P}$ & $(68.28)$ & $(0.00)$ & $(16.83)$ & $(14.89)$ & $(100.00)$ \\
& 61 & 0 & 30 & 113 & 204 \\
$\mathbf{P} \rightarrow \mathbf{N P}$ & $(29.90)$ & $(0.00)$ & $(14.71)$ & $(55.39)$ & $(100.00)$ \\
& 324 & 1 & 434 & 417 & 1176 \\
$\mathbf{N P} \rightarrow \mathbf{N P}$ & $(27.55)$ & $(0.09)$ & $(36.90)$ & $(35.46)$ & $(100.00)$ \\
& 145 & 2 & 240 & 1299 & 1686 \\
& $(8.60)$ & $(0.12)$ & $(14.23)$ & $(77.05)$ & $(100.00)$ \\
\hline & 1374 & 3 & 912 & 2013 & 4302 \\
\hline
\end{tabular}

(B) Multinomial logit model with trade variables (equation D-Table 4)

The poverty status of about 61.46 percent of households was correctly predicted.

\begin{tabular}{lccccc}
\hline \multirow{2}{*}{ Actual } & \multicolumn{5}{c}{ Prediction } \\
\cline { 2 - 5 } \\
\cline { 2 - 5 } $\mathbf{P} \rightarrow \mathbf{P} \rightarrow \mathbf{P}$ & $\mathbf{N P} \rightarrow \mathbf{P}$ & $\mathbf{P} \rightarrow \mathbf{N P}$ & $\mathbf{N P} \rightarrow \mathbf{N P}$ & \\
& 861 & 1 & 215 & 159 & 1236 \\
$\mathbf{N P} \rightarrow \mathbf{P}$ & $(69.66)$ & $(0.08)$ & $(17.39)$ & $(12.86)$ & $(100.00)$ \\
& 61 & 2 & 31 & 110 & 204 \\
$\mathbf{P} \rightarrow \mathbf{N P}$ & $(29.90)$ & $(0.98)$ & $(15.20)$ & $(53.92)$ & $(100.00)$ \\
& 317 & 1 & 468 & 390 & 1176 \\
$\mathbf{N P} \rightarrow \mathbf{N P}$ & $(26.96)$ & $(0.09)$ & $(39.80)$ & $(33.16)$ & $(100.00)$ \\
& 127 & 4 & 242 & 1313 & 1686 \\
& $(7.53)$ & $(0.24)$ & $(14.35)$ & $(77.88)$ & $(100.00)$ \\
\hline
\end{tabular}

Note: The predicted probabilities of falling into the 4 different categories were first calculated and each household was allocated to the category for which the probability was the highest.

is for equation (D) of Table 4 (our preferred equation) than for the base equation with no trade component (see Appendix). The increase in the pseudo- $\mathrm{R}^{2}$ from 0.234 to 0.266 suggests that trade adds a further 3.2 percent to the explained variation in poverty experience but that much of the latter remains unexplained. The proportions of correct predictions from the MNL model tell a similar story (see Table 5). The basic model classifies 59.9 percent of households correctly, over-predicting no-change outcomes $(\mathrm{P} \rightarrow \mathrm{P}$ and $\mathrm{NP} \rightarrow \mathrm{NP})$ and under-predicting the 
changes - see block A. Its inability to pick up descent into poverty is palpable but hardly surprising, but it also misses a significant number of 'escapees': indeed only 36.9 percent of actual escapees are correctly identified. ${ }^{28}$ Adding the trade variables improves the overall success rate, though slightly, by about 1.5 percentage points or 2.5 percent - see block (B). In particular, we correctly identify more of the escapees from poverty increasing the success rate to 39.6 percent. These are modest improvements, to be sure, but let us re-iterate that they are statistically significant in the estimating equation and that in terms of targeting compensatory policies even a 2 percentage point improvement is worth achieving.

\section{E. The Effect on Poverty}

The results so far offer some plausible evidence that international trade reform has affected individual household poverty dynamics in Vietnam, and that by taking it into account we are better able to predict which households prosper and which do not. This lends considerable weight to the analytical approach proposed and to the view that 'trade matters'. It does not, however, tell us directly whether trade reform reduced poverty. For that, we need to create a counterfactual - '1998 without trade reform' - and it is here that the uncertain division of responsibility between trade policy, other policies and exogenous shocks really takes its toll.

As noted above we use initial household characteristics as variables and infer the change in their value between 1992-1993 and 1997-1998 from the coefficients. Hence, we can estimate the effects of trade reform on overall poverty by setting the 'trade-related' coefficients to zero (the corresponding odds ratio to unity) and recalculating the predicted changes in poverty. ${ }^{29}$ For some effects, however, the change in the value of a characteristic is due to things other than trade, so the appropriate reduction for this exercise may be less than 100 percent. For the sake of illustration we also consider reductions of one-half in these coefficients.

Table 6 summarises the effects of setting various 'trade' coefficients in the MNL model to zero [odds ratio, $\mathrm{OR}=1$ ] and to one half of their estimated value $\left[\mathrm{OR}^{\prime} \approx 1+1\right.$ /

\footnotetext{
${ }^{28}$ The predictions underestimate the degree of change at least partly because, unlike the actuals, they ignore the random variance in the system (around 75 percent of the total). If our interests were in predicting the proportion of changes per se we would replicate these simulations many times adding in a suitably distributed random variable and calculate an average transition matrix over these replications. However, we are interested in comparing two simulations (with and without trade) so we do not need to do this.

${ }^{29}$ Because we standardised the variables in the regression equation, we also need to subtract $\beta \bar{x} / s$ from the constant to ensure that the equations go through the same mean point as before, where $\bar{x}$ is the mean value of the trade variable, $s$ its standard deviation and $\beta$ the trade coefficient set to zero.
} 
Table 6. Poverty Reductions due to Trade Reforms

\begin{tabular}{lrrrr}
\hline & \multicolumn{2}{c}{ A: Solely due to trade reforms } & \multicolumn{2}{c}{ B: Partially (half) due to trade reforms } \\
\cline { 2 - 5 } & $\begin{array}{l}\text { Escape from } \\
\text { Poverty }\end{array}$ & 1998 Poverty & $\begin{array}{c}\text { Escape from } \\
\text { Poverty }\end{array}$ & \multicolumn{1}{c}{1998 Poverty } \\
\hline Rice & $-1(0.02 \%)$ & $-226(5.25 \%)$ & $-1(0.02 \%)$ & $-113(2.63 \%)$ \\
Coffee & $+8(0.19 \%)$ & $-12(0.28 \%)$ & $+5(0.12 \%)$ & $-7(1.63 \%)$ \\
Fertilisers & $+186(4.32 \%)$ & $-292(6.79 \%)$ & $+87(2.02 \%)$ & $-141(3.28 \%)$ \\
Export employment & $-12(0.28 \%)$ & $-61(1.42 \%)$ & $-11(0.26 \%)$ & $-31(0.72 \%)$ \\
All & $+250(5.81 \%)$ & $-668(15.53 \%)$ & $+96(2.23 \%)$ & $-296(6.88 \%)$ \\
\hline
\end{tabular}

Note: The coefficients on the variable for rice production and on those interacted with the regional dummies (the Mekong River Delta and the Red River Delta) are controlled for rice. For fertilisers, the coefficients on the quantity of fertilisers used for rice as well as for non-rice are controlled. As for export employment, the coefficients on the ratio of household members working in the export sector and on the change in the ratio are controlled. The figures are the unweighted number of households and those in parentheses are the percentage of the households in the panel data set.

2(OR-1)], in equation from column (D) of Table 4. The predicted numbers of households in each category from equation (D) are given at the foot of Table 5 block B. These figures were then recalculated with various combinations of trade coefficients set to zero to isolate the contribution of trade. ${ }^{30}$ Thus, for example, if none of the trade effects had applied, about 250 fewer households would have escaped from poverty and 668 more would have been in poverty in 1998. Out of 4,302 households in total, these are considerable contributions. The table also reports the figures for individual trade effects and reveals that the critical variable appears to be fertiliser use. The small negative figures for rice and export employment arise because, although these variables have a positive partial effect on the chances of escaping from poverty, they also affect the predictions of the household's chances of being in another category and the prediction is made by choosing the category with the highest predicted probability. In both cases the suppression of the trade effects switches households from $\mathrm{P} \rightarrow \mathrm{NP}$ to $\mathrm{P} \rightarrow \mathrm{P}$, as we would predict, but this is dominated numerically by those who are switched from $\mathrm{NP} \rightarrow \mathrm{NP}$ to $\mathrm{P} \rightarrow \mathrm{NP}$. If trade effects are set to half the estimated coefficients (block B), the contribution of trade reform is still large - nearly 100 additional households escaping from poverty (about 10 percent of those that did) and nearly 300 fewer households in poverty (about 10 percent again).

\footnotetext{
${ }^{30}$ This exercise is essentially a simulation. We are comparing predictions under two sets of conditions, not actual and predicted values.
} 


\section{F. Sensitivity Tests}

The results just described allow some confidence that we have located some of the effects of trade reform in the dynamics of individual households. Two caveats are in order, however. First, the trade effects included in this exercise are not exhaustive: there will be other channels through which trade has impacted poverty dynamics. This is not a problem with the regression results, unless these other factors are correlated with our included effects. We have identified systematic effects and these will continue to exist even if there are others. It is a problem for calculating the net effect of trade reform on poverty because the omitted effects could be either reinforcing or offsetting to our included effects. All we claim is that the channels we have identified had a beneficial effect. The second caveat is that while it would be desirable to control for unobserved household characteristics that may influence poverty transitions it is not possible to do so as there are only two waves of data.

Despite these caveats, the econometric analysis suggests that the trade reforms of the 1990s influenced the poverty transitions of Vietnamese households. The significant effects accord well with the shocks identified in the discussion of trade policy (although not all those identified could be included), and given that we use only initial variables we are free from worries about endogeneity. Indeed the predictive power of the initial variables gives strong support to their use in ex ante predictions of the effects of liberalisation as made by, for example, Ravallion and van de Walle (1991) for Indonesia and Minot and Goletti (1998) for Vietnam. Nonetheless, it is desirable to push the model a little harder to test its sensitivity. We conducted two such tests. ${ }^{31}$

First, we re-estimated the multinomial logit model with a wider band at which households change their status. This enables us to check whether the errors of observation or random shocks to income flows are correlated with our independent data. We find that re-estimating equation (D) in Table 4 excluding any household that was within \pm 10 percent of the poverty line in either year leaves the results largely unscathed. ${ }^{32}$ Among the trade variables, the results on falling back into poverty are even less significant, while for escaping from poverty the most notable

\footnotetext{
${ }^{31}$ The results of these alternative models are not reported here (see Niimi et al. (2003) for details).

${ }^{32}$ This is a demanding test because it excludes the households most likely to change their poverty status. This may introduce some selection bias, but our prime purpose of this exercise is to examine the robustness our earlier results.
} 
differences are the insignificance of rice production in the Mekong River Delta, the smaller and less significant effects of coffee production, and the larger effects of fertiliser use. Among non-trade variables, the major change is the decline into insignificance of the household head having university education.

The second sensitivity test asks, quite independent of poverty lines, what determines changes in income? It is a simple regression of changes in total household expenditure on the various determinants discussed so far. Given the absence of any information about poverty at all, this approach is even more vulnerable to concerns that it is dominated by the experiences of a few households and so we estimate the regression model on both the full sample and a truncated sample comprising the second to sixth deciles of the initial income distribution. The results differ very significantly between the samples. Overall, the trade variables are jointly significant at 5 percent even if they are not so individually, but their signs are not plausible. It is worth re-iterating, however, that all our independent data refer to initial conditions, so this is a far tougher test than, say, the decompositions used by Dercon (2002) for Ethiopia, in which expenditure changes are related to initial characteristics and changes in them. These results are disappointing for our maintained view that trade policy has affected poverty directly, but they are not entirely nugatory. Since poverty is our focus we draw comfort from the MNL model over the less robust linear regression approaches.

\section{Conclusion}

This paper makes two contributions. Methodologically, for the first time it implements and examines empirically the usefulness of a conceptual framework linking trade liberalisation and extreme poverty. While clearly not explaining anything like the full extent of Vietnam's poverty dynamics, it shows that the framework is plausible and adds significantly to our understanding of and ability to predict the poverty impact of trade reform. Substantively, the paper has suggested that despite its incompleteness and hesitancy, trade reform in Vietnam over the 1990s reduced poverty. Exports and imports boomed and the prices of some tradable goods increased strongly. We find signs of these effects in the household data, with the real incomes of the poor tending to increase via their engagement in the rice, coffee and light manufactures sectors. These last results are significant both statistically and economically, and although they are not wholly robust, they are suggestive and represent, we believe, the first time that international trade 
variables have been formally traced through into ex post household poverty data.

\section{Acknowledgements}

This paper is part of the project "The Impact of Trade Reforms and Trade Shocks on Household Poverty Dynamics" (ESCOR-R7621) funded by the UK Department for International Development, for the benefit of developing countries, as part of their Globalisation and Poverty Research Programme. Views and opinions expressed in the paper are, however, those of the authors alone. We are grateful to the World Bank for making the trade data available for the DFIDfunded Globalisation and Poverty Research Programme's projects on Vietnam. The paper draws freely on work by and discussion with our colleagues in the Poverty Research Unit, Sussex, Patricia Justino and Julie Litchfield. We are also grateful for comments on earlier drafts from colleagues in The Economics Subject Group at Sussex, participants in the University of Warwick's Conference on "Globalisation, Growth and (In)Equality", March 2002, the DfID Seminar on "Globalisation and Poverty" in Hanoi, September 2002, and the OECD Development Centre Conference on "How are Globalisation and Poverty Interacting?" in Paris, December 2002, and from Bob Baulch, Rhys Jenkins, Niel McCulloch, Andy McKay, Chantal Nielsen, David O'Connor, Lina Song, Finn Tarp, Shujie Yao and Linxiu Zhang.

Received 18 June 2005, Accepted 26 June 2007

\section{APPENDIX: REGRESSION RESULTS OF MULTINOMIAL LOGIT MODELS (Odds Ratios)}

Model 1: Without trade variables

Model 2: With trade variables

\begin{tabular}{|c|c|c|c|c|c|c|}
\hline & \multicolumn{2}{|c|}{$\mathbf{N P} \rightarrow \mathbf{P}$} & \multicolumn{2}{|c|}{$\begin{array}{c}\mathbf{P} \rightarrow \mathbf{N P} \\
\text { (Escaping Poverty) }\end{array}$} & \multicolumn{2}{|c|}{$\mathbf{N P} \rightarrow \mathbf{N P}$} \\
\hline & Model 1 & Model 2 & Model 1 & Model 2 & Model 1 & Model 2 \\
\hline \multicolumn{7}{|c|}{ Geographic characteristics } \\
\hline Urban & 0.911 & 0.998 & $* * 1.716$ & $* * * 1.979$ & $* * * 2.442$ & $* * * 3.231$ \\
\hline Northern Uplands & 1.412 & 1.726 & 1.188 & 1.257 & 1.155 & 1.325 \\
\hline $\begin{array}{l}\text { Red River Delta } \\
\text { (North Central) }\end{array}$ & 1.082 & 1.814 & $* * 1.445$ & $* * 1.667$ & 1.261 & $* * * 2.489$ \\
\hline Central Cost & 1.523 & 1.650 & 0.986 & 0.970 & $* * * 2.658$ & $* * * 2.706$ \\
\hline Central Highlands & 1.282 & 0.830 & $* * 2.256$ & 1.019 & $* * * 6.600$ & $* * 3.177$ \\
\hline South East & $* * * 3.965$ & $* * * 3.879$ & $* * * 5.423$ & $* * * 4.736$ & $* * * 19.678$ & $* * * 18.482$ \\
\hline Mekong River Delta & $* * * 5.027$ & $* * * 4.580$ & $* * * 2.126$ & $* * * 2.175$ & $* * * 9.605$ & $* * * 8.213$ \\
\hline
\end{tabular}




\begin{tabular}{|c|c|c|c|c|c|c|}
\hline & \multicolumn{2}{|c|}{$\mathbf{N P} \rightarrow \mathbf{P}$} & \multicolumn{2}{|c|}{$\begin{array}{c}\mathbf{P} \rightarrow \mathbf{N P} \\
\text { (Escaping Poverty) }\end{array}$} & \multicolumn{2}{|c|}{$\mathbf{N P} \rightarrow \mathbf{N P}$} \\
\hline & Model 1 & Model 2 & Model 1 & Model 2 & Model 1 & Model 2 \\
\hline \multicolumn{7}{|l|}{ Ethnicity } \\
\hline \multicolumn{7}{|l|}{ (Kinh) } \\
\hline Chinese & 1.806 & 1.905 & 0.765 & 0.715 & $* 3.952$ & $* * 4.883$ \\
\hline Other ethnicity & 0.864 & 1.006 & $* * * 0.386$ & $* * * 0.430$ & $* * * 0.359$ & $* * * 0.453$ \\
\hline \multicolumn{7}{|c|}{ Demographic characteristics } \\
\hline Female head of household & 0.994 & 1.058 & 0.984 & 1.016 & 1.085 & 1.197 \\
\hline Age of household head & 0.951 & 0.959 & $* * * 1.305$ & $* * * 1.316$ & $* * * 1.456$ & $* * * 1.464$ \\
\hline No. of males $60+$ & 0.968 & 0.925 & 0.918 & $* 0.895$ & *0.879 & $* * * 0.829$ \\
\hline No. of females $55+$ & 1.122 & 1.085 & 1.092 & 1.074 & $* 1.118$ & 1.076 \\
\hline No. of males $19-59$ & 0.997 & 0.933 & 0.993 & 0.942 & 0.977 & $* 0.892$ \\
\hline No. of females 19-54 & 1.138 & 1.070 & $* 1.115$ & 1.073 & $* * 1.152$ & 1.073 \\
\hline No. of children $15-18$ & 0.969 & 0.889 & 1.029 & 0.969 & $* * 0.893$ & $* * * 0.782$ \\
\hline No. of children 6-14 & $* * * 0.460$ & $* * * 0.411$ & $* * 0.887$ & $* * * 0.807$ & $* * * 0.631$ & $* * * 0.538$ \\
\hline No. of children 3-5 & $* * * 0.604$ & $* * * 0.560$ & $* * * 0.760$ & $* * * 0.725$ & $* * * 0.520$ & $* * * 0.475$ \\
\hline No. of infants $0-2$ & $* * * 0.581$ & $* * * 0.558$ & $* * * 0.784$ & $* * * 0.765$ & $* * * 0.548$ & $* * * 0.515$ \\
\hline \multicolumn{7}{|l|}{ Education variables } \\
\hline \multicolumn{7}{|l|}{ Head } \\
\hline \multicolumn{7}{|l|}{ (No education) } \\
\hline Primary school & $* * 1.688$ & $* * 1.706$ & $* * * 1.835$ & $* * * 1.833$ & $* * * 2.126$ & $* * * 2.066$ \\
\hline Lower secondary school & $* * 1.779$ & $* * 1.836$ & $* * * 2.844$ & $* * * 2.834$ & $* * * 3.455$ & $* * * 3.548$ \\
\hline Upper secondary school & 1.584 & 1.764 & $* * * 3.227$ & $* * * 3.343$ & $* * * 6.734$ & $* * * 7.564$ \\
\hline Tech/voc school & 1.275 & 1.383 & $* * * 1.989$ & $* * * 2.023$ & $* * * 4.696$ & $* * * 5.132$ \\
\hline University & $* * * 1.35 \mathrm{e}-14$ & $* * * 2.00 \mathrm{e}-14$ & $* * 10.061$ & $* * * 12.707$ & $* * * 46.400$ & $* * * 69.795$ \\
\hline \multicolumn{7}{|l|}{ Spouse } \\
\hline \multicolumn{7}{|l|}{ (No spouse) } \\
\hline No education & 1.097 & 1.038 & 0.938 & 0.887 & 1.128 & 1.083 \\
\hline Primary school & 1.061 & 1.043 & 1.073 & 1.087 & $* * 1.637$ & $* * 1.699$ \\
\hline Lower secondary school & 1.222 & 1.209 & 1.061 & 1.052 & 1.273 & 1.294 \\
\hline Upper secondary school & $* * 2.966$ & $* * 3.096$ & 1.454 & 1.426 & $* * * 2.399$ & $* * * 2.447$ \\
\hline Tech/voc school & $* 2.913$ & $* * 3.230$ & $* * * 2.735$ & $* * * 3.021$ & $* * * 6.234$ & $* * * 7.334$ \\
\hline University & $* * * 4.62 \mathrm{e}-15$ & $* * * 4.43 \mathrm{e}-15$ & 2.409 & 2.251 & $* * * 6.413$ & $* * * 6.214$ \\
\hline \multicolumn{7}{|l|}{ Occupations (Head) } \\
\hline White collar & $* * * 5.733$ & $* * * 6.111$ & $* * * 3.291$ & $* * * 3.528$ & $* * * 7.465$ & $* * * 8.349$ \\
\hline Sales/Services & 1.657 & $* 2.168$ & 1.498 & $* * 1.846$ & $* * * 3.252$ & $* * * 5.065$ \\
\hline \multicolumn{7}{|l|}{ (Agriculture) } \\
\hline Production & 1.185 & 1.234 & 0.966 & 1.167 & 1.249 & $* * 1.608$ \\
\hline
\end{tabular}




\begin{tabular}{|c|c|c|c|c|c|c|}
\hline & \multicolumn{2}{|c|}{$\mathbf{N P} \rightarrow \mathbf{P}$} & \multicolumn{2}{|c|}{$\begin{array}{c}\mathbf{P} \rightarrow \mathbf{N P} \\
\text { (Escaping Poverty) }\end{array}$} & \multicolumn{2}{|c|}{$\mathbf{N P} \rightarrow \mathbf{N P}$} \\
\hline & Model 1 & Model 2 & Model 1 & Model 2 & Model 1 & Model 2 \\
\hline Not working & 0.678 & 0.745 & $* * * 0.604$ & $* * 0.634$ & 0.783 & 0.939 \\
\hline \multicolumn{7}{|l|}{ Illness shock } \\
\hline $\begin{array}{l}\text { Household head ill for more } \\
\text { than a week in past } 4 \text { months }\end{array}$ & $* * 1.828$ & $* * 1.995$ & 1.221 & 1.249 & 1.030 & 1.090 \\
\hline \multicolumn{7}{|l|}{ Infrastructure } \\
\hline Access to electricity & 1.422 & 1.381 & $* * * 1.541$ & $* * * 1.446$ & $* * * 3.481$ & $* * * 3.364$ \\
\hline Road & 0.620 & 0.733 & $* * * 1.666$ & $* * 1.605$ & $* * 0.680$ & 0.768 \\
\hline Food shop & 1.409 & 1.459 & $* * * 1.611$ & $* * * 1.766$ & $* * * 2.190$ & $* * * 2.317$ \\
\hline Daily market & $* * * 2.015$ & $* * * 2.205$ & 1.093 & 1.208 & $* * * 1.512$ & $* * * 1.613$ \\
\hline Primary school & 0.456 & 0.441 & 0.782 & 0.767 & $* 0.496$ & $* * 0.483$ \\
\hline Lower secondary school & 1.110 & 1.030 & 0.872 & 0.792 & $* * 1.382$ & 1.164 \\
\hline Upper secondary school & 1.091 & 1.175 & 1.042 & 1.098 & $* * 1.565$ & $* * * 1.736$ \\
\hline Post office & $* * * 0.566$ & $* * 0.561$ & $* * * 0.622$ & $* * * 0.619$ & $* * * 0.378$ & $* * * 0.363$ \\
\hline Clinic & 1.634 & 1.531 & $* * * 1.923$ & $* * * 1.756$ & $* * 1.701$ & $* * * 1.841$ \\
\hline \multicolumn{7}{|l|}{ Agricultural variables } \\
\hline Quantity of rice production & & 1.769 & & $* * * 1.753$ & & $* * * 3.445$ \\
\hline In Mekong River Delta & & 0.752 & & $* * 0.601$ & & $* * * 0.505$ \\
\hline In Red River Delta & & $* * 0.710$ & & $* * 0.845$ & & $* * * 0.612$ \\
\hline Quantity of coffee production & & $* * * 2.358$ & & $* * * 2.315$ & & $* * * 2.359$ \\
\hline Quantity of fertiliser for rice & & $* * * 1.679$ & & $* * * 1.460$ & & $* * * 1.491$ \\
\hline Quantity of fertiliser for non-rice & & 1.557 & & $* 1.696$ & & $* * 1.969$ \\
\hline \multicolumn{7}{|l|}{ Trade variables } \\
\hline $\begin{array}{l}\text { Ratio of household members } \\
\text { working in export }{ }^{(1)} \\
\text { to number of adults }\end{array}$ & & $* * * 1.649$ & & $* * * 1.254$ & & $* * * 1.517$ \\
\hline Change in the ratio ${ }^{(2)}$ & & $* 1.186$ & & $* * 1.173$ & & $* * 1.169$ \\
\hline Duration between two surveys & 0.932 & 0.920 & $* * * 1.500$ & $* * * 1.432$ & $* * * 1.375$ & $* * * 1.394$ \\
\hline \multicolumn{7}{|l|}{$\begin{array}{l}\text { Seasonality } \\
\text { (Interviewed 1st quarter) }\end{array}$} \\
\hline Interviewed 2nd quarter & 0.626 & 0.629 & 1.054 & 1.065 & 0.928 & 0.960 \\
\hline Interviewed 3rd quarter & 0.941 & 1.156 & $* * 1.341$ & $* * * 1.594$ & $* * * 1.821$ & $* * * 2.190$ \\
\hline Interviewed 4th quarter & 0.820 & 0.788 & $* * * 1.845$ & $* * * 1.668$ & $* * * 1.965$ & $* * * 1.994$ \\
\hline
\end{tabular}




\begin{tabular}{lrrrrrr}
\hline & \multicolumn{2}{c}{$\mathbf{N P} \rightarrow \mathbf{P}$} & \multicolumn{2}{c}{$\mathbf{P} \rightarrow \mathbf{N P}$} & \multicolumn{2}{c}{ NP $\rightarrow$ NP } \\
\hline & Model 1 & Model 2 & Model 1 & Model 2 & Model 1 & Model 2 \\
\hline No. of observations & 4,302 & 4,302 & 4,302 & 4,302 & 4,302 & 4,302 \\
Pseudo R & 0.234 & 0.266 & 0.234 & 0.266 & 0.234 & 0.266 \\
\hline Souring Poverty)
\end{tabular}

Source: Calculations based on the VLSS 92-93 and 97-98.

Note: $* * *$ significant at 1 percent level; ** significant at 5 percent level; * significant at 10 percent level. (1) The export sector includes seafood, food processing, garment and shoes (+rubber and plastic products).

(2) It should be noted that the categories for occupation slightly differ between the VLSS 92-93 and the VLSS 97-98.

\section{References}

Andersen, H. (1994) Vietnam at the Crossroads, Macroeconomic Studies, 55/94, Stockholm: Planning Secretariat, SIDA.

Apoteker, T. (1998) Vietnam: Trade and Investment Analysis: 1998 Update, A Report for the European Commission, Vietnam.

Belser, P. (1999) Vietnam: On the Road to Labour-Intensive Growth?, Policy Research Working Paper, No.2389, Washington, D. C.: World Bank.

Benjamin, D. and Brandt, L. (2004) Agriculture and Income Distribution in Rural Vietnam under Economic Reforms: A Tale of Two Regions, in Economic Growth, Poverty, and Household Welfare in Vietnam (Ed.), Glewwe, P., Agrawal, N. and Dollar, D., Washington, D.C.: World Bank.

Burgess, S., Gardiner, K., Jenkins, S. and Propper, C. (2000) Measuring Income Risk, ISER Working Paper, 2000-15, Institute for Social and Economic Research, University of Essex.

Chandrasiri, S and de Silva, A. (1996) Globalisation, Employment and Equity: The Vietnam Experience, Regional Office for Asia and the Pacific: Bangkok, ILO/EASMAT project. Central Institute for Economic Management (CIEM) (2000) Vietnam's Economy in 1999, Hanoi: Statistical Publishing House.

(2001) An Overview of Vietnam's Trade Policy in the 1990s, manuscript.

This is an updated version of An Overview of Vietnam's Trade Policies, by The Technical Group of TLCV in Vietnam's Socio-Economic Development, No.19, Autumn, 1999.

Centre of International Economics (CIE) (1998) Vietnam's Trade Policies 1998, Canberra and Sydney: CIE.

Deaton, A. (1989) Rice Prices and Income Distribution in Thailand: A Non-Parametric Analysis, Economic Journal, 99, 1-37.

(1997) The Analysis of Household Surveys: A Microeconomic Approach to

Development Policy, World Bank: The John Hopkins University Press. 
Dercon, S. (2002) The Impact of Economic Reforms on Rural Households in Ethiopia: A Study from 1989 to 1995, Poverty Dynamics in Africa Series, Washington, D.C.: World Bank.

Falaris, E. M. (2003) The Effect of Survey Attrition in Longitudinal Surveys: Evidence from Peru, Côte d'Ivoire and Vietnam, Journal of Development Economics, 70, 133157.

Gallup, J.L. (2004) The Wage Labour Market and Inequality in Vietnam in the 1990s, in Economic Growth, Poverty, and Household Welfare in Vietnam (Ed.), Glewwe, P., Agrawal, N. and Dollar, D., Washington, D.C.: World Bank.

General Statistics Office (GSO), various issues, Statistical Yearbook, Hanoi: Statistical Publishing House.

Glewwe, P., Gragnolati, M. and Zaman, H. (2002) Who gained from Vietnam's boom in the 1990s?, Economic Development and Cultural Change, 50(4), 773-792.

International Monetary Fund (IMF) (1998) Vietnam: Selected Issues and Statistical Appendix, Staff Country Report, No.98/30, Washington D.C.: IMF.

(1999) Vietnam: Selected Issues, Staff Country Report, No. 99/55, Washington D.C.: IMF.

(2000) Vietnam: Statistical Appendix, Staff Country Report, No. 00/116, Washington D.C.: IMF.

Justino, P. and Litchfield, J. (2002) Poverty Dynamics in Vietnam: Winners and Losers during Reform, PRUS Working Paper, No.10, Poverty Research Unit, University of Sussex.

(2004) Welfare in Vietnam during the 1990s: Poverty, Inequality and Poverty Dynamics, Journal of the Asia Pacific Economy, 9(2), 145-169.

Kokko, A. (1997) Vietnam 1997: Managing the Transition to Free Trade: Vietnamese Trade Policy for the 21st Century, Macroeconomic Reports, 1997:4, Stockholm: SIDA.

Martin, W. (2000) Achieving High Growth: Experience of Transitional Economies in East Asia, Paper for presentation to the International Conference on Achieving High Growth: Experience of Transitional Economies in East Asia, Australian National University, September 6-7, 2000.

Minot, N., 1998, Competitiveness of the Food Processing Sector in Vietnam: a Study of the Rice, Coffee, Seafood and Fruits and Vegetables Subsectors, Appendix I of the Industrial Competitiveness Review, UNIDO.

Minot, N. and Goletti, F. (1998) Export Liberalisation and Household welfare: the Case of Rice in Vietnam, American Journal of Agricultural Economics, 80, 738-749.

Nielsen, C. P. (2002) Vietnam in the International Rice Market, Fødevare $\phi$ konomisk Institute Rapport, No.132, Copenhagen: Fødevareøkonomisk Institute.

Niimi, Y., Vasudeva-Dutta, P. and Winters, L. A. (2003) Trade Liberalisation and Poverty Dynamics in Vietnam, PRUS Working Paper, No.17, Poverty Research Unit, University of Sussex.

(2004) Storm in a Rice Bowl: Rice Reform and Poverty in Vietnam in the 
1990s, Journal of the Asia Pacific Economy, 9(2), 170-190.

(forthcoming (2005)) Linking Trade Liberalisation and Poverty: An Illustration from Vietnam in the 1990s, in Globalisation and Poverty: Channels and Policy Responses (Ed.), Bussolo, M. and Round, J., Routledge.

O'Connor, D. (1996) Labour Market Aspects of State Enterprise Reform in Viet Nam, OECD Development Centre.

Ravallion, M. (1996) Issues in Measuring and Modelling Poverty, Economic Journal, 106, 1328-1343.

Ravallion, M. and van de Walle, D. (1991) The Impact on Poverty of Food Pricing Reforms: A Welfare Analysis for Indonesia, Journal of Policy Modelling, 13, 281299.

Singh, I., Squire, L. and Strauss, J. (1986) A Survey of Agricultural Household Models: recent Findings and Policy Implications, World Bank Economic Review, 1, 149-79.

van Donge, J. K, White, H. and Nghia, L. W. (1999) Fostering High Growth in a Low Income Economy, Stockholm: SIDA.

White, H. and Masset, E. (2003) The Importance of Household Size and Composition in Constructing Poverty Profiles: An Illustration from Vietnam, Development and Change, 34(1), 105-126.

Winters, L. A. (2000) Trade and Poverty, Is There a Connection?, in Trade, Income Disparity and Poverty (Ed.) Ben David, D., Nordstrom, H. and Winters, L. A., Geneva: WTO. (2002) Trade Liberalisation and Poverty: What Are the Links?. The World Economy, 25, 1339-1367.

World Bank (1999) Vietnam Development Report 2000: Attacking Poverty, Donor-NGO Working Group, Consultative Group Meeting for Vietnam, December 14-15, 1999. (2000) Vietnam Living Standards Survey 1992-93: Basic Information, Washington, D.C. World Bank. (2001) Vietnam Living Standards Survey 1997-98: Basic Information, Washington, D.C.: World Bank. 